\title{
Gish Abay: the source of the Blue Nile
}

\author{
T. Oestigaard ${ }^{1} \&$ A. F. Gedef ${ }^{2}$ \\ ${ }^{1}$ The Nordic Africa Institute, Uppsala, Sweden \\ ${ }^{2}$ Department of Archaeology, History, Cultural Studies and Religion, \\ University of Bergen, Norway
}

\begin{abstract}
The river Nile is by many seen as the most important river in the world. The source of the Blue Nile is a spring called Gish Abay in Ethiopia. This is the source of Gilgal Abay (meaning the little Abay), which is the most voluminous of the some sixty rivers flowing into Lake Tana. Although the Nile Quest has attracted emperors and explorers alike since Antiquity, after the sources of the Nile were discovered the majority of studies have focused on hydrology and not on cultural and religious aspects of the river. Gish Abay has been seen as the outlet of the river Gihon flowing directly from Paradise linking this world with Heaven. The holiness of Abay and the source in particular have had and still have an important role in the Ethiopian Orthodox Church. Moreover, before the source was Christianised it had a central role in the indigenous religion where lavish ox sacrifices were conducted. Thus, in this article we highlight the ritual and religious role of Gish Abay in a historic perspective.
\end{abstract}

Keywords: Blue Nile, Gish Abay, ox sacrifice, religion, rituals, source, water.

\section{Introduction}

The secrets of the Nile sources and their mysteries have from the dawn of civilisation attracted philosophers, emperors and explorers, and the search for the source of the Nile was a big quest in antiquity onwards to the nineteenth century. However, despite the importance of the river Nile since antiquity, very little research has been conducted on the cultural and religious aspects of the Blue Nile in general and the source Gish Abay in particular. As Major Robert Cheesman noted in 1935, 'When I was first appointed to North West Ethiopia, in 1925, as His Majesty's Consul, I found that very little was known of the Blue 
Nile in Abyssinia, and determined to see and survey the whole valley from its source at the Sacred Spring at Gish Abbai, through Lake Tana, and down to Roseires in the Sudan, a distance of about 600 miles' [1]. Still, more than eighty years later, few studies have been conducted emphasising the beliefs and rituals starting from Gish Abay and following the Blue Nile to Lake Tana and further on. Therefore, in this article we will briefly address the search of the source of the Blue Nile in Ethiopia, give some short descriptions of rituals and beliefs as documented in historical records and thereafter present new ethnographic data with regards to practices and beliefs at the source of the Blue Nile - Gish Abay.

\section{The search for the source}

According to father Balthazar Tellez, who wrote The Travels of the Jesuits in Ethiopia in 1710, "it was said of Alexander the Great that the first question he asked when he came to Jupiter Ammon was where the Nile had its rise, and we know that he sent discoveries throughout Ethiopia without being able to find out this source' [2]. About Julius Caesar it is said that he 'was so desirous of knowing this spring that, discoursing in Egypt with that grave old man Achoreus, and enquiring where the Nile had its origin, he went so far as to tell him it was the thing he most coveted to know in the world... adding that he would quit his country Rome for the satisfaction of discovering that source' [3]. Later, Emperor Nero sent two centurions to discover the source of the Nile, but failed, and the soldiers seem to have reached the Sudd [4].

Ptolemy is often credited as the first one who identified the origin of the Nile from Lake Victoria and Albert and the mountain range the Mountains of the Moon (Ruwenzori) [5]. Ptolemy mentions also a Lake of Koloe, which geographers have discussed whether could have been a perception of Lake Tana [6]. It has also been suggested, based on interpretations of old maps, that Ptolemy's lakes were in Abyssinia - Lake Tana and probably Lake Ashangi and that the source of the Nile and the Mountains of the Moon are associated [7]. Ptolemy was the authority on the sources of the Nile until the end of the fifteenth century and the latest edition of his map was published in 1485 [8].

The first Europeans visiting the source of the Blue Nile were probably the Portuguese who were sent to Ethiopia with Christopher de Gama in 1541. Exactly when they saw the source for the first time is uncertain since they did not document the event, but some of the Portuguese remained in Ethiopia and finally settled at Nanina, which is only some fifty kilometres from the source [9].

The Portuguese Jesuit priest Pedro Paez was the first European who described the source, the river and Lake Tana in his History of Ethiopia. He visited the source on 21 April 1618 (or 1613). In the Portuguese Jesuit Father Lobo's book the year 1613 is given, but James Bruce argues with reference to the native Abyssinian chronicles that Paez' visit probably was in 1615. Finally, the Jesuit Athanasius Kircher, who published a Latin version of Paez' account of his travels in 1652, give the date 21 April 1618 [10]. Lobo also visited the source in the years around 1629, and he described it as such: 'This spring, or rather these two springs, are two holes, each about two feet in diameter, a stone's cast 
distance from each other. The one is but about five feet and an half in depth...Of the other, which is somewhat less...we could find no bottom, we were assured by the inhabitants that none ever had been found. It is believed here that these springs are the vents of a great subterranean lake' [11]. Lobo's manuscript was translated into English and published by the Jesuit Father F. Balthazar Telles in London in 1670 [12].

James Bruce, who was born in 1730 at Kinnaird in Scotland, was an explorer who travelled from Cairo to the source of the Blue Nile (fig. 1). When Bruce finally came to Gish Abay November 4, 1770, he believed - or at least claimed to the rest of the world when he published his accounts - that he was the first European who visited the spring. Bruce published in 1790 his Travels to discover the source of the Nile: in the years 1768, 1769, 1770, 1771, 1772, and 1773, in five volumes [13]. Bruce claimed that Paez' account of his visit at the source was a modern interpolation, and he uses a number of pages in volume three to argue that Paez never visited the source.

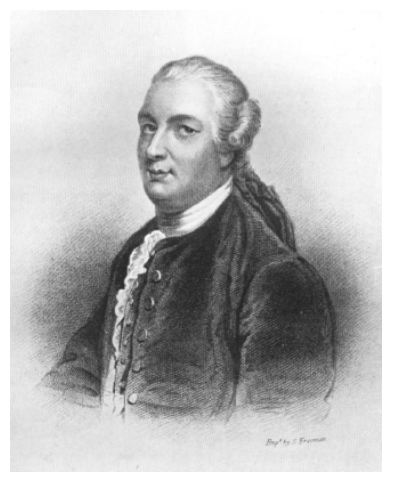

Figure 1: James Bruce. From Johnston 1903, face page 86.

The extraordinary and grandiose feeling of finding the source may explain the desire to be that very explorer who found the ultimate source of life, in particular since the Nile Quest had been at the central heart of exploration for more than two millennia. In the words of Bruce:

'It is easier to guess than to describe the situation of my mind at that moment - standing in that spot which had baffled the genius, industry, and inquiry of both ancients and moderns, for the course of near three thousand years. Kings had attempted this discovery at the head of armies, and each expedition was distinguished from the last, only by the difference of the numbers which had perished, and agreed alone in the disappointment which had uniformly, and without exception, followed them all. Fame, riches, and honour, had been held out fore series of ages to every individual of those myriads these princes commanded, without having produced one man capable of gratifying the curiosity of his sovereign, or wiping off this stain upon the enterprise and abilities of mankind, or adding this desideratum for the encouragement of 
geography. Though a mere private Briton, I triumphed here, in my own mind, over kings and their armies...'Strates, said I, faithful squire, come and triumph with your Don Quixote at the island of Barataria where we have wisely and fortunately brought ourselves; come and triumph with me over all the kings of the earth, all their armies, all their philosophers, and all their heroes' [14].

Bruce's dishonest claim that he was the first European who visited the source of the Blue Nile was completely exposed in 1796 by Professor Hartmann in his Edrisii Africa. Dr. Charles T. Beke wrote in 1847: 'The attempt made by our countryman to deprive Paez of the merit of having anticipated him in the discovery and description of the source of Abái, or supposed Nile, must ever remain a sad blot on the fame to which he had sufficient legitimate claims, without seeking to appropriate to himself what justly belonged to others' [15].

\section{The early explorers and researchers at the source}

Bruce pays a lot of attention to the importance and holiness of the Nile and its source, and in particular to the cult of sacrificing oxen. The source itself is called 'God of Peace', indicating the particular holiness of this very spot. 'The Agows of Damot pay divine honour to the Nile; they worship the river, and thousands of cattle have been offered, and still are offered, to the spirit supposed to reside at its source....all the tribes...meet annually at the source of the river, to which they sacrifice, calling it by the name of the God of Peace' [16]. The ox sacrifice is then described:

'It is upon the principle fountain and altar, already mentioned, that once ayear, on the first appearance of the dog-star, (or, as others say, eleven days after) this priest assembles the heads of the clans; and having sacrificed a black heifer that never bore a calf, they plunge the head of it into this fountain, they then wrap it up in its own hide, so as no more to be seen, after having sprinkled the hide within and without with water from the fountain. The carcase is then split in half, and cleaned with extraordinary care; and, thus prepared, it is laid upon the hillock over the first fountain, and washed all over with its water, while the elders, or considerable people, carry water in their hands joined (it must not be in any dish) from the two other fountains; they then assemble upon the small hill a little west of St Michael, (it used to be the place where the church now stands) there they divide the carcase into pieces corresponding to the number of the tribes' [17].

Charles T. Beke visited the source of the Blue Nile twice in 1842, the first time on 26 March, and he was the first to scientifically document the course of the Blue Nile. He also gives important descriptions of the source and the ritual practices which still were conducted at that time: 
'On questioning my guides as to the celebration of religious ceremonies, they scorned the idea of their performing anything of the sort, being Christians; but they admitted that yearly in the month of Hedár, or Tahsás (about the end of November), after the rainy season, and when the ground is sufficiently dry to allow it, an ox is slaughtered on the spot by the neighbouring Shum, and its blood is allowed to flow into the spring, its flesh being eaten on the ground. I could not learn that any particular ceremonies accompany this act. Also at the close of the Abyssinian year (the beginning of September), on the eve of St. John, sick persons are brought hither and left for seven days, which they say ensures their recovery. Logs of wood have from time to time been laid around the source to serve as a bed for these sick visitants... These practices are evidently remains of a higher degree of veneration paid to the spot at a period when the inhabitants of the country were not converted to Christianity' [18].

When Beke returned to Gish Abay on 23 December the circumstances were quite different from his first visit. Due to the unusual quantity of the rain, the whole area was saturated with water and he continuously sank up to the ankles in the mud. Upon his arrival he sent for a priest, who told him that the church was known by three names; A'shihi St. Michael, Abái minch (source) St. Michael, and Gíesh St. Michael. The priest had brought his cross from the church which he blessed the water with before Beke could drink it. 'On my inquiring what form of words he used, he was reluctant to answer. I asked, "Do you say, In the name of the Father, Son, and Holy Ghost?" "Yes." "Nothing else?" "Nothing else." But this assertion is not to be relied on, and I may remark that I found him apparently averse to answer any questions' [19].

Major R. E. Cheesman had several trips to Lake Tana and the two first expeditions were in 1927 and 1929. In 1932-33 he was surveying the Lake Tana monasteries and his wife joined him to the source. When Cheesman visited Gish Abay, he inquired about Zerabruk. The church at Gish Abay is dedicated to both St. Michael and Zerabruk. Some has suggested that the name Zerabruk was a corruption of Bruce's name, and Bruce only mentions St. Michael Gish in his book. The priests at Gish Abay, however, told Cheesman that Zerabruk was a saint, but according to him, they had no idea who he was [20]. However, rather than to commemorate Bruce, Zerabruk has a specific meaning, and in Amharic zarburuk means 'blessed seed' [21].

Cheesman received holy water from a priest, but when the priest heard that he had eaten that day, he insisted that Cheesman had to wait until the next day and drink the water before breakfast. The water loses its healing and curative power if it is taken after food, but more importantly, it could be deadly. Several people, who had ignored this warning and had been drinking the holy water after a meal, had died. Similarly, when Cheesman visited the source with his wife in 1933, the priests took them to the spring. When she touched the water with the end of her stick, the surrounding pilgrims shouted: 'Don't let her touch it, She is a woman'. She asked the priest what evil could inflict upon her if she took a bath in the spring, and he replied that 'You would die' [22]. 
When Cheesman inquired about the history of the church, a priest and several of his parishioners all agreed that it was founded in the reigns of Yohannes Kadus or John the Holy (John I, 1667-1682), and that the Ark came from Gonder. Apparently, the church was built by money donated by a woman named Bujet from Gonder. Her mother Iniya had brought Bujet to Gish to drink the water from the spring hoping to be cured from complaints the 'doctor' could not relieve. Bujet recovered and fell in love with the chieftain of Sakala, who she married, and refused to go back to Gonder. Following Cheesman, there are no other references to Bujet or Iniya, but near Gish there is a small tributary to the Abay which is called the Bugeta, which may commemorate Bujet and her marriage [23].

\section{Gish Abay today}

The holiness of Gish Abay has its origin in both Old Testament and New Testament contexts. In the Genesis it is written: 'A river watering the garden flowed from Eden; from there it was separated into four headwaters. The name of the first is the Pishon; it winds through the entire land of Havilah, where there is gold. The name of the second river is the Gihon; it winds through the entire land of Cush. The name of the third river is the Tigris; it runs along the east side of Asshur. And the fourth river is the Euphrates' (Genesis 2:11-14). Before the Nile was called Abay its name was Gihon. Gihon, which is one of the four rivers from heaven and the Garden of Eden also apparent on earth, has its outlet at Gish Abay. Hence, Gish Abay is the direct source from heaven and it is consequently a physical intake and outlet to the divine spheres where the life-giving waters come from. According to the priests, 'Gihon feeds the heaven', 'Gihon has served heaven' and 'Gihon has rotated the world seven times and has fed the water for the heaven, and has come back to Ethiopia'. The river is always moving and circulating. It feeds the heaven in the East and it comes out in Ethiopia. All water in its different forms such as rain and small streams join the Nile and represents a circle. Heaven was the first place where Adam and Eve and hence humanity lived. Thus, Gihon has always served humanity. When Adam and Eve lived in Heaven, Gihon was a life-giving river in Paradise, and when humanity was expelled from Paradise, Gihon flowed from heaven to earth. Thus, in Ethiopia Gihon may also be seen as a source of Christianity and a source to be a Christian and a pathway to Heaven. Since humans are dependent upon the Nile and its water for survival, the water can be seen as a covenant between humans and God since God penalises people with too little or too much water if they are sinful and disobedient.

There are two particular religious stories with regards to the holiness of the Nile on earth, one relating to Gihon and the other to Abay and Gish Abay. Following the Bible, the four divine rivers in heaven have different qualities and characteristics; one consists of honey, another of oil, the third of wine and Gihon consists of milk. When these rivers are flowing on earth they do not contain the divine substances as honey, oil, wine and milk, but the holy waters appear as clear and normal water. According to the priests at Gish Abay, when Jesus was 
born all the earthly counterparts of these divine rivers changed from being clear as holy water to their divine qualities for one day. Gihon River turned into milk from where it has derived its name from; Milk Abay. The day after Jesus' birth all the divine rivers returned to their earthly characteristics containing normal clear and holy water. The other story is about the introduction of Christianity in this area, the miracles of Zerabruk and why the Nile is called Abay and its source Gish Abay.

Abune Zerabruk was born from his father Kidus Deme Christos and mother Kidist Mariam Mogessa at the end of the eighth century AD. (The words Kidus and Kidist literary connote the term 'blessed' for male and female respectively) Before his birth, one of his forefathers is said to have told a myth about a man who would be born from his seventh generation of the maternal line who with his prayers and sacrifices would save the world.

Abune Zerabruk was a man of religious character from his early days. At about the age of 7, the Abune prayed to God asking him to make him blind so he could not see all the evil deeds of the secular world. Accordingly, he became blind for twelve years. Then on, the Abune went to different places for religious education and eventually to monasteries during which he is said to have performed a number of miracles, religious deeds and achievements. He also prayed for about thirty years at the source of river Abay, which was to become Gish Abay.

According to the legend of the Church, the Abune received from God the power to cure people for their physical diseases and spiritual sins by using water. Before he used the water for healing he had to bless the stream (Gish Abay) in the name of the Father, the Son and the Holy Spirit. People using this water would also gain eternal life. Even people who were not yet baptised could be considered as being baptised from that time onwards since they had used the water from Gish Abay, or Gihon, which the river then was called.

Due to the growing popularity with regards to his religious deeds and powers, the Abune eventually faced difficulties and obstacles with regional rulers. Prior to his stay around Abay/Gihon where he prayed, he was forced to leave the place Tsima because of political resistance against his religious teaching. At Gish Abay he was eventually arrested by the king's soldiers. Before he was arrested, the Abune stood at the source of Gihon River, one of the main waters or rivers believed to be the source of heaven, prayed and finally gave his seven sacred books to the source of the river. It is also claimed that God told him to give the books to the river. He was imprisoned for five years during which some destructive forces or events were said to have happened in the jail, and as a result, the king released the Abune. After five years in prison and two years of teaching and preaching at different places, the Abune finally came back to the source of Abay where he had kept his books. The Abune prayed thoroughly and devoted to God and asked the river to bring forth the books he had given in custody while he was taken to prison.

Gish means 'bring forth', and when Zerabruk stood at the source of the Nile where he had deposited the seven sacred book seven years earlier, he said gish bring forth. Then the river brought forth the books to the surface, which were 
undamaged after being hidden in the water. Surprised and pleased of this miracle, the Abune asked his old disciple Aba Zerufael to look at the miracle. He said 'Aba Eyi' in Amharic, which means 'Father, look', directing the disciple's attention to the fact that the river brought the books to the surface without being damaged. 'Aba Eyi' became Abay, which is the Ethiopian name for the Blue Nile. Hence, the name of the holy river and in particular the source - Gish Abay - refers to this religious event. After this miracle the river changed its name from Gihon to Abay. When the river changed the name from Gihon to Abay, it got a masculine character, which is indicated by the Amharic term 'Aba Eyi' 'Father, look'.

Lobo writes: 'The Nile, which the natives call Abavi, that is, the Father of Waters' [24]. 'Abay' connotes normally to greatness, strongness and splendour and hence the river has masculine association and is a male river. However, Abay may in Geez, which is the old church language still in use, also connote 'big' or 'great' in terms of women or the feminine, and Abay may indicate a woman or a girl whereas Abei signifies a man or boy. After the miracles of Zerabruk, Abay has a particular etymology as it signifies 'motherhood' or the 'feminine', and as a mother for her devotees she is a life-giver providing wealth, prosperity and everything that is bountiful. In Geez Abay means the quality of being a woman signifying motherhood and fertility representing the feminine, and it can also be a female name. Still, the feminine connotation is not the primary interpretation, and the Blue Nile is first and foremost seen as a masculine and male river. As Tafla argues, the Nile was simply the river or the father of rivers, and the Geez adjective 'Abbawi' means 'fatherly'. Ethiopian lexicographers believed that one reason for describing the river as father was that the river unites so many tributaries like a father who gathers together his children [25]. One may also add that in the language of the Agows, gish means 'dig' and thus Gish Abay becomes 'Dig father'.

Gish Abay refers to the source of both secular and spiritual life. It is believed that people who are baptised or sprinkled with the Gihon River in the name of the holy water of Abay/Ye Abay tsebel are cured of any sins, sicknesses and misfortunes. This is because, as the Church claims, the Abune once again prayed at Gishen for many years. On the behalf of the Abune, it is believed that God had vindicated all his mercy up to seventy generations on the descendants of the devotees who used the water of this river and prayed at the source.

Abune Zerabruk died at the age of 482 years and was buried at Tsima Silasie, where he previously had prayed, healed and made miracles. His seven sacred books have since his death been kept in the monastery at Gish Abay as the most auspicious and sacred treasures.

These are neither accessible to the public nor to the monks, and today only one living priest has seen them, and the books are allegedly still in a perfect condition. Since the holy books are not visible or accessible to anyone but still of utmost, religious importance, the monastery sells copies of an edited Amharic version of the sacred books, which this information is partly based upon.

The continuity of older rituals conducted at Gish Abay has been pervasive. Next to the church of Zerabruk where the water from the source forms the stream 
which later becomes the Nile, it was common to present sacrifices to the river and this tradition has only disappeared during the last decade or so. If devotees prayed for healing from sickness and suffering, they would turn a chicken three times around their head before throwing it to the river. Similarly, if women prayed for fecundity, they would present the Bible three times around their head while praying for having children. These rituals are, however, not performed any longer since prayers and the blessing of the water used by the people are more in accordance with the Orthodox teaching.

Gish Abay is a major pilgrimage site where not only local people attend the services collecting and becoming blessed by the holy water, but pilgrims from all over the country come to the source and the greatest festival when most pilgrims attend takes place on 13 January (the Ethiopian calendar), which is the celebration and holy day of Zerabruk.

The main ceremony takes place in the St. Mikael Church which houses both the Ark of Michael and Zerabruk. The church service starts early in the morning. St. Mikael Church is located at the upper hill area from where, after the devotees have partaken in the church services and prayed, the pilgrims go down the slope to the source of the Blue Nile. Within a small compound area there are two churches. The source itself is located in a small church named after Zerabruk. Although the real source is also believed to be in another church, which is just some few meters away from the Zerabruk Church at a little higher elevation and where only priests are admitted entrance, it is the Zerabruk Church which is perceived as the most important.

Some pilgrims take full ablution whereas other queue up in line in front of the church with plastic bottles and cans (fig. 2). When the devotees take full ablution and ritual baths at the very source within the church, they do not need any assistance by priests or monks. There are two entrances to the source which are covered by a cloth. Women use the left entrance and men the right one. Depending upon the devotees' experiences, the purification process may be felt as an exorcism driving evil spirits out of the body.

When devotees want to collect holy water and use it later, they do not have direct access to the source. Church attendants and assistants fill the water in bottles and cans which will be blessed by priests. After the devotees have collected water from the source and received the bottles, and some have taken full ablution within the Church, everyone proceeds to the church Manbebya kifle, literally meaning Reading room, where the preaches and blessing of the water take place before they are blessed by the holy water through the priests' sprinkling of it on them (fig. 3). The water is holy in itself, but when it is blessed again by priests, additional holiness is attributed to the water.

The holy water which is used for blessings is healing and life-giving for any kind of sickness and malignance as well as it cleanses the devotees for sins. After drinking the holy water, the effects may be immediate, but it may also take days, months and even years before the prayers are fulfilled. Moreover, as indicated, the effects of this holy water is not only limited to the actual pilgrims praying at Gish Abay, but may work miracles for the descendants up to seventy generations. 


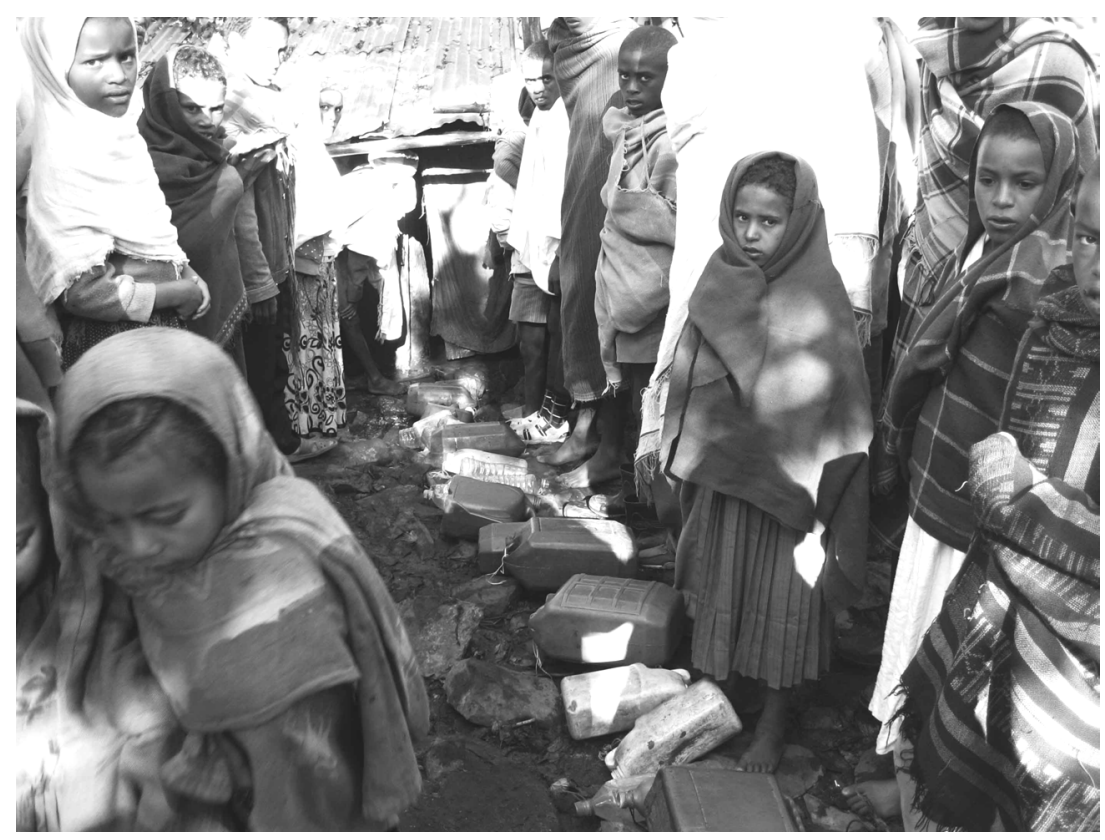

Figure 2: $\quad$ Gish Abay - the source of the Blue Nile.

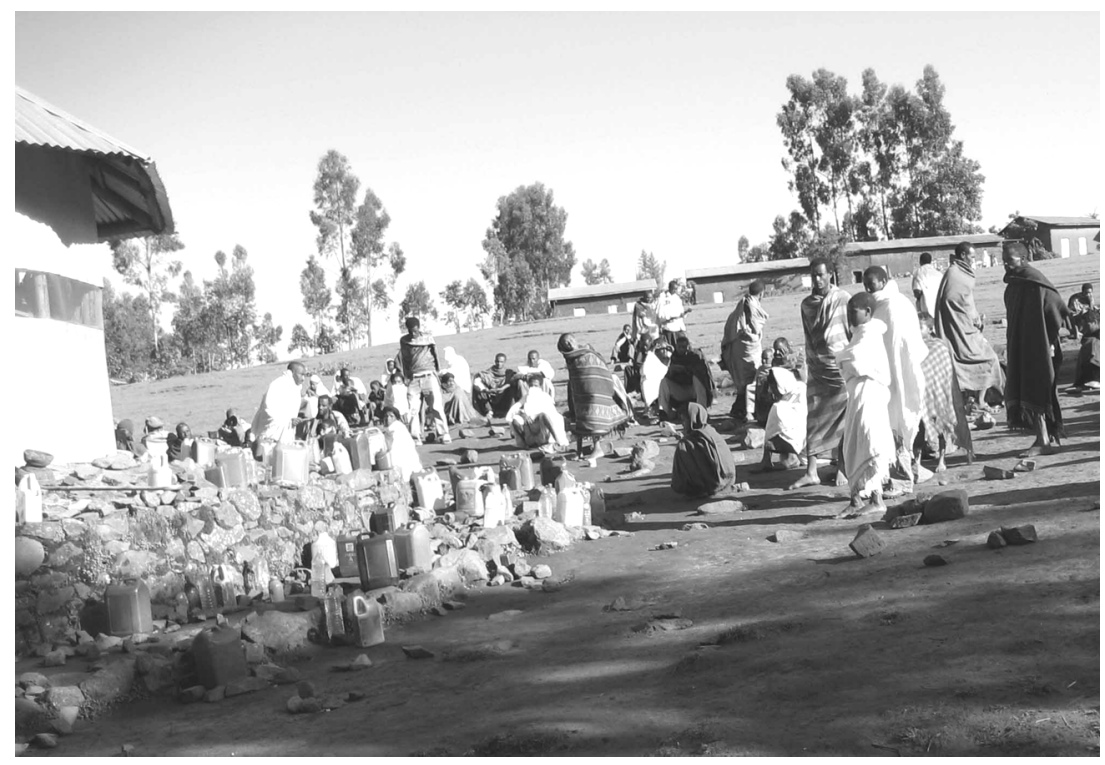

Figure 3: Manbebya kifle where the water is blessed by priests. 


\section{Conclusion}

The source of the Nile has been surrounded by myths since the dawn of civilisation onwards. Emperors and explorers searched for the source in vain, and the source of the Blue Nile was discovered by Portuguese missionaries in the seventeenth century. Still, it is James Bruce who has left the largest imprint on this spring with his vivid and detailed descriptions of the rituals and sacrifices in particular and of Abyssinia in general. Today, this mythological place lives on and has gone through a long process of Christianisation. Although the ox sacrifices to the source have ceased as a ritual practice, the indigenous religious traditions and beliefs have had a long continuity at Gish Abay. With the beliefs that Gish Abay is the source from heaven, the source has still a fundamental role in cosmology and Christianity.

\section{References}

[1] Cheesman, R. E. 1935. Lake Tana and Its Island. The Geographical Journal, Vol. 71, No. 4: 358-374.

[2] op.cit Cheesman, R. E. 1968[1936]. Lake Tana and the Blue Nile. An Abyssinian Quest. Frank Cass \& Co. Ltd. London, p. 13.

[3] ibid.

[4] Budge, E. A. W. 1928. A History of Ethiopia. Nubia \& Abyssinia. Methuen \& Co, Ltd. London, 112.

[5] Johnston, H. 1903. The Nile Quest. Lawrence and Bullen, Ltd. London, p. 22-23.

[6] Bent, T. J. 1893. The Ancient Trade Route across Ethiopia. The Geographical Journal, Vol. 2, No. 2: 140-146, p. 142.

[7] Crawford, O. G. S. 1949. Some Medieval Theories about the Nile. The Geographical Journal, Vol. 114, No. 1/3: 6-23, 19.

[8] Johnston, H. 1903. The Nile Quest. Lawrence and Bullen, Ltd. London, p. 25.

[9] Friedlander, M. J. 2007. Ethiopia's Hidden Treasures. A guide to the paintings of the remote churches of Ethiopia. Shama Books. Addis Ababa, p. 67.

[10] Johnston, H. 1903. The Nile Quest. Lawrence and Bullen, Ltd. London, p. 51.

[11] Lobo, J. 1789. A voyage to Abyssinia, by Father Jerome Lobo, a Portuguese Missionary. Containing the history, natural, civil, and ecclesiastical, of that remote and unfrequented country, continued down to the beginning of the eighteenth century: with fifteen dissertations relating to the antiquities, government, religion, manners, and natural history, of Abyssina. By m. Le Grand; Translated from the French by Samuel Johnson, LL.D. ; To which are added, various other tracts by the same author, not published by Sir John Hawkins or Mr Stockdale. London: printed for Elliot and Kay, and C. Elliot, Edinburgh, p. 110-111. 
[12] Johnston, H. 1903. The Nile Quest. Lawrence and Bullen, Ltd. London, p. 64.

[13] Bruce, J. 1790. Travels to Discover the Source of the Nile, in the Years 1768, 1769, 1770, 1771, 1772, and 1773 in Five Volumes. J. Ruthven. London.

[14] Bruce 1790 Vol. 3: 597-598.

[15] Beke, C. T. 1847. On the Nile and Its Tributaries. Journal of the Royal Geographical Society of London, Vol. 17:1-84, p. 14-15.

[16] Bruce 1790 Vol. 3:633.

[17] Bruce 1790 Vol. 3:730.

[18] Beke, C. T. 1844. Abyssinia: Being a Continuation of Routes in That Country. Journal of the Royal Geographical Society of London, Vol. 14:1- 76, p. 13.

[19] Beke 1844:34.

[20] Cheesman, R. E. 1928. The Upper Waters of the Blue Nile. The Geographical Journal, Vol. 85, No. 6: 489-502; Cheesman, R. E. 1935. Lake Tana and Its Island. The Geographical Journal, Vol. 71, No. 4: 358374.

[21] Beckingham, C. F. \& Huntingford, G. W. B. 1954. Some Records of Ethiopia 1593-1646. Being Extracts from The History of High Ethiopia or Abassia by Manoel De Almeida. Together with Bahrey's History of the Galla. Printed for the Hakluyt Society. London, p. 29, fn. 1.

[22] Cheesman, R. E. 1968[1936]. Lake Tana and the Blue Nile. An Abyssinian Quest. Frank Cass \& Co. Ltd. London, p. 73.

[23] ibid:74.

[24] Lobo 1789: 110.

[25] Tafla, B. 2000. The Father of Rivers: The Nile in Ethiopian Literature. In Erlich, H. \& Gershoni, I. (eds.). The Nile. Histories, Cultures, Myths: 153-170. Lynne Rienner Publishers. London, p. 155, 167-168. 